Zeszyty Naukowe Szkoły Głównej Gospodarstwa Wiejskiego w Warszawie

Problemy Rolnictwa Światowego tom 18 (XXXIII), zeszyt 4, 2018: 481-492

DOI: 10.22630/PRS.2018.18.4.136

Ewa Wasilewska $^{1}$, Lukasz Pietrych ${ }^{2}$

Szkoła Główna Gospodarstwa Wiejskiego w Warszawie

\title{
Starzenie się społeczeństwa a wzrost gospodarczy w krajach Unii Europejskiej
}

\section{Demographical Ageing and Economic Growth in the UE Countries}

\begin{abstract}
Synopsis. Z uwagi na wciąż pogłębiający się proces demograficznego starzenia się ludności i znaczenie skutków tego procesu dla gospodarki, w artykule poddano analizie relację pomiędzy starzeniem się społeczeństwa krajów Unii Europejskiej a wzrostem gospodarczym. Celem podjętych badań była próba określenia wpływu starzenia się społeczeństwa na dynamikę wzrostu gospodarczego w krajach UE 27. Okres badań obejmował lata 1996-2016, dane pochodziły z bazy Eurostatu oraz Banku Światowego. Na potrzeby badań uwzględniono podział na kraje „starej” Unii i „,nowej” Unii. Za miare wzrostu gospodarczego przyjęto tempo wzrostu PKB, natomiast uwzględnionymi miarami starości demograficznej były stopa starości (odsetek osób w wieku $65+\mathrm{w}$ populacji) oraz współczynnik sędziwej starości (odsetek osób w wieku $80+$ w populacji). Wykorzystano modele panelowe. Stwierdzono, że demograficzne starzenie się społeczeństwa ujemnie koreluje z dynamiką wzrostu gospodarczego. W skonstruowanych modelach panelowych dla krajów „starej” Unii współczynniki regresji odpowiadające stopie starości i współczynnikowi sędziwej starości wynosiły odpowiednio: $-0,446$ oraz $-1,521$, podczas gdy dla krajów „nowej” Unii były równe: $-0,153$ (dla stopy starości) oraz $-0,980$ (dla współczynnika sędziwej starości). Oznacza to, że negatywny wpływ starzenia się ludności na tempo wzrostu PKB jest silniejszy w krajach „starej” Unii w porównaniu z krajami „nowej” Unii.
\end{abstract}

Słowa kluczowe: starzenie się ludności, wzrost gospodarczy, Unia Europejska, modele panelowe

\begin{abstract}
Due to the still growing demographic aging process and the significance of this process on the economy, the article analyzes relationship between the demographic aging of the European Union countries and economic growth. The aim of the research was to determine the impact of demographic aging on the rate of economic growth in the EU27. The research period covered the years 2000-2015. Data from the Eurostat and the World Bank databases were used. The study adopted a division into the "old" and "new" EU Member States. The rate of GDP growth was taken as the measure of economic growth, while the measures of demographic aging included the old-age rate (percentage of population aged 65 or over) and the venerable senility rate (share of the population at the age of 80 or more in the general number of population). Panel models were used. It was found that the demographical aging of society negatively correlates with the dynamics of economic growth. In panel models constructed for countries of the "old" Union, regression coefficients for the old-age rate and the venerable senility rate were respectively: $-0,446$ and $-1,521$, while for the "new" EU countries were equal to: $-0,153$ (for the old-age rate) and $-0,980$ (for the venerable senility rate). This means that the negative impact of demographic aging on the GDP growth rate is more strongly observed in the countries of the "old" Union in comparison with the countries of the "new" Union.
\end{abstract}

Key words: demographical ageing, economic growth, European Union, panel models

JEL Classification: C23, C51, J10, J11, O11

${ }^{1}$ dr, Katedra Ekonomiki Rolnictwa i Międzynarodowych Stosunków Gospodarczych SGGW w Warszawie, ul. Nowoursynowska 166, 02-787 Warszawa, e-mail: ewa_wasilewska@sggw.pl; https://orcid.org/0000-0001-9065-5526

${ }^{2}$ dr, Katedra Ekonomiki Rolnictwa i Międzynarodowych Stosunków Gospodarczych SGGW w Warszawie, ul. Nowoursynowska 166, 02-787 Warszawa, e-mail: lukasz_pietrych@sggw.pl; https://orcid.org/0000-0001-5053-3890 


\section{Wprowadzenie}

Demografia, jako nauka o zjawiskach ludnościowych w oczywisty sposób związana jest $\mathrm{z}$ ekonomią. Prawidłowości w rozwoju gospodarczym kraju czy regionu zawsze bowiem wynikają z określonych decyzji i zachowań człowieka (Śleszyński, 2010). Wpływ procesów ludnościowych na życie gospodarcze dostrzegano już w starożytności. Platon i Arystoteles wskazywali, że problemy gospodarcze Grecji wynikały z nadmiaru ludności w stosunku do obszaru i małej urodzajności gleby. Platon był zwolennikiem ograniczenia liczby ludności, Arystoteles dowodził, że nadmierny wzrost liczby ludności może doprowadzić do zmniejszenia potęgi kraju i sprowadzić choroby społeczne. W starożytnym Rzymie natomiast propagowano szybki wzrost liczby ludności, jako źródło potęgi państwa (Zając, 2007). W XVI w. francuski uczony Jean Bodin formułował tezę, że ludność jest źródłem siły i bogactwa państwa, gdyż liczba mieszkańców oznacza w prosty sposób zwiększenie potencjału gospodarczego i militarnego (Śleszyński, 2010). Korzyści z dużej i rosnącej liczby ludności podnoszone były też na gruncie teorii merkantylizmu (XVI-XVII w.). Wskazywano na korzyści gospodarcze z dużej i rosnącej liczby ludności, propagowano politykę popierającą zawieranie związków małżeńskich, duże rodziny, poprawę zdrowia publicznego, kontrolowaną emigrację i imigrację (Podstawowe..., 2013). Ludność była uważana za ważny czynnik bogactwa narodowego, toteż popieranie przyrostu ludności było jednym z najważniejszych celów polityki merkantylistycznej (Zając, 2007).

Pierwszą próbę sformułowania zwartej teorii rozwoju ludności w powiązaniu z rozwojem ekonomicznym podjął na przełomie XVIII i XIX w. ekonomista angielski T.R. Malthus. Według T.R. Malthusa liczba ludności wzrasta w postępie geometrycznym $(1,2,4,8,16, \ldots)$ i podwaja się co 25 lat, a produkcja środków żywnościowych - w postępie arytmetycznym $(1,2,3,4,5, \ldots)$, co grozi katastrofą (Podstawowe..., 2013).

Zainteresowanie ekonomistów kwestiami demograficznymi początkowo sprowadzało się jedynie do analiz wpływu wielkości populacji oraz tempa jej wzrostu na procesy gospodarcze. Dopiero w późniejszym okresie dostrzeżono, iż obok liczby ludności znaczenie ma również jej wewnętrzna struktura. Gdy w drugiej połowie XX w. populacje zaczęły się intensywnie starzeć, pojawiła się potrzeba głębszej refleksji naukowej nad następstwami procesu starzenia się społeczeństwa (Jurek, 2012).

Starzenie się społeczeństwa, tj. wzrost udziału ludności w starszym wieku (65 lat i więcej) wśród ogółu mieszkańców, jest skutkiem przemian demograficznych polegających na przejściu od wysokich do niskich wskaźników umieralności oraz wskaźników płodności (Bloom i in., 2003). Podstawową konsekwencją zachodzącej transformacji demograficznej jest istotny spadek zasobów pracy, co musi przekładać się niekorzystnie na perspektywy wzrostu gospodarczego. Zmniejsza się bowiem grupa ludności mająca najistotniejszy wpływ w kreowaniu PKB, a wzrasta znacząco grupa świadczeniobiorców (Strzelecki, 2012).

Należy jednak wskazać, że zarazem to właśnie wzrost gospodarczy jest jednym z ważniejszych czynników determinujących procesy demograficzne. Tak więc między demografią a wzrostem gospodarczym występują złożone sprzężenia zwrotne, które nie łatwo jest skwantyfikować. Rezultaty tych wzajemnych powiązań zależą bowiem od wielu czynników, zarówno ilościowych, jak i jakościowych (Mączyńska, 2010). Jednym z czynników ilościowych jest struktura wiekowa ludności, a ta z kolei określa poziom starości społeczeństwa.

W. Florczak i M. Przybyliński (2016) wskazują na wzajemne powiązania procesów 
ekonomicznych i demograficznych uzasadniając, iż można przyjąć, że uwarunkowania ekonomiczne są endogeniczne względem rozwoju demograficznego. Autorzy wyjaśniają, że uwarunkowania ekonomiczne wpływają jedynie na strumienie procesów demograficznych i przyczyniają się do zmian w oczekiwanej długości życia, co w krótkim okresie nieznacznie wpływa na poziom zasobów demograficznych. Natomiast oddziaływanie zasobów demograficznych na procesy ekonomiczne jest natychmiastowe i kluczowe, co wyraża się np. w podaży pracy.

Zmniejszające się zasoby pracy spowodowane starzeniem się społeczeństwa stają się ogromnym wyzwaniem dla tworzenia PKB (Strzelecki, 2012). Siła robocza jest kluczowym czynnikiem produkcji, a zatem jej ubytek, będący następstwem spadku liczby ludności w wieku produkcyjnym, przekłada się bezpośrednio na zmniejszenie się produkcji/PKB ogółem (Florczak, Przybyliński, 2016).

W literaturze przedmiotu badania podejmujące związek procesów demograficznych ze wzrostem gospodarczym są bardzo skromne. Ograniczają się na ogół do analiz wpływu zmian liczebności populacji na tempo wzrostu gospodarczego (w ujęciu globalnym i per capita). Kompleksowa, przejrzysta teoria łącząca wzrost gospodarczy z liczbą oraz strukturą ludności nie została dotychczas wypracowana. Jak podaje Śleszyński (2010, s. 57): „najczęściej wymieniana w podręcznikach demografii i ekonomii teoria (właściwie quasi-teoria) rozwoju transformacji demograficznej nie jest explicite rozwiązaniem wiążącym ściśle wzrost, stagnację lub spadek gospodarczy z odpowiednimi ilościowymi procesami demograficznymi w przestrzeni".

Wobec wciąż pogłębiającego się procesu starzenia się ludności oraz znaczenia skutków tego procesu dla rozwoju gospodarczego istotne jest prowadzenie analiz w zestawieniu: procesy demograficzne-wzrost gospodarczy. Celem podjętych badań była próba kwantyfikacji wpływu starzenia się społeczeństwa na dynamikę wzrostu gospodarczego w krajach Unii Europejskiej (UE 27). Jednostką badawczą był kraj, przy czym z badań wyłączona została Chorwacja ze względu na brak danych. W opracowaniu przyjęto za Florczakiem i Przybylińskim (2016), że procesy gospodarcze są endogeniczne względem procesów demograficznych.

Analizą objęto okres 1996-2016. Materiał empiryczny stanowiły dane publikowane przez Eurostat oraz Bank Światowy. Do wykonania niezbędnych obliczeń wykorzystano program GRETL.

\section{Metoda badań}

Z uwagi na charakter danych (dane panelowe), do realizacji przyjętego celu wykorzystane zostały modele panelowe. Terminem „dane panelowe” określa się dane, powstające z połączenia szeregów czasowych obserwacji dla jednostek przekrojowych. Modele panelowe (ang. panel data models) to modele ekonometryczne szacowane na podstawie danych panelowych. W przypadku takich modeli zakłada się, że na kształtowanie się zmiennej objaśnianej wpływają oprócz zmiennych objaśniających, pewne niemierzalne, stałe w czasie i określone dla danego obiektu czynniki, zwane efektami indywidualnymi (lub grupowymi) (Dańska-Borsiak, 2009).

Badania przeprowadzone $\mathrm{z}$ zastosowaniem modeli panelowych do analiz ekonometrycznych prezentują L. Mátyás, P. Sevestr (2008). Wagę stosowania modeli panelowych podkreślają także m.in. H.-J. Andreß, K. Golsch oraz A. Schmidt-Catran 
(2013). Modele te z powodzeniem mogą być stosowane w analizie zjawisk ekonomicznych, w szczególności dla realizacji celu sygnalizowanego w niniejszym opracowaniu.

Ze względu na coraz większe zainteresowanie modelami panelowymi w objaśnianiu kształtowania się zjawisk ekonomicznych, w literaturze przedmiotu dokonano podziału danych panelowych na mikropanele i makropanele. Mikropanele to dane, które charakteryzują się dużą liczbą obserwacji przekrojowych oraz niewielka liczbą obserwacji opisujących poszczególne obiekty w czasie (jako przykład można tutaj wymienić dane dotyczące gospodarstw indywidualnych). Makropanele natomiast są to zbiory danych, które cechuje mniejsza liczba obserwacji przekrojowych oraz dłuższy szereg czasowy, sięgający kilkudziesięciu okresów (jako przykłady można tutaj wymienić dane makroekonomiczne dotyczące państw Unii Europejskiej) (Dańska-Borsiak, 2011).

Najprostszym sposobem estymacji parametrów strukturalnych modelu panelowego jest estymator panelowy $M N K$. Jednakże w przypadku wykorzystania tego estymatora należy przyjąć dosyć restrykcyjne założenia mówiące o homogeniczności populacji oraz tym, że różnice zachodzące pomiędzy rzeczywistymi wartościami zmiennej zależnej, a wartościami teoretycznymi są jedynie następstwem występowania składnika losowego (Geise, 2013). W praktyce założenia te są trudne do spełnienia ze względu na niejednorodność badanych populacji. Koniecznym jest zatem uwzględnienie w modelu różnić pomiędzy poszczególnymi obiektami w postaci efektów stałych lub losowych. W związku z tym wprowadzono rozróżnienie i wyodrębniono (Maddala, 2008; Dougherty, 2011):

- modele z efektami stałymi (ustalonymi) (ang. fixed effects regression models), które stosuje się w przypadku stwierdzenia występowania efektów indywidualnych. Zakłada się przy tym występowanie nieznanych (nieobserwowalnych), ale stałych w czasie różnic pomiędzy obiektami. Model taki ma postać:

$$
y_{i t}=x_{i t} \beta+\mu_{i}+\varepsilon_{i t},
$$

gdzie $\mu_{i}$ jest to stały w czasie efekt indywidualny $i$-tego obiektu, $\varepsilon_{i t}$ - czysty błąd losowy dla $i$-tego obiektu w czasie $t$;

- modele z efektami losowymi (modele z dekompozycją składnika losowego) (ang. random effects regression models), w których każdej jednostce przypisuje się pewną zmienną losową, której realizacja odpowiada za efekt indywidualny $\mu_{i}$ w danym okresie. Łączny błąd losowy składa się wtedy z efektu indywidualnego (efektu losowego $\mu_{i}$ ) oraz czystego błędu losowego $\varepsilon_{i t}$. koniecznym staje się wtedy zastosowanie uogólnionego estymatora najmniejszych kwadratów (UMNK).

Ze względu na możliwość występowania efektów indywidualnych, modele panelowe powinny zostać podawane testom statystycznym weryfikującym zasadność ich zastosowania. Celem tych testów jest wskazanie najbardziej odpowiedniej metody estymacji parametrów strukturalnych modeli. W literaturze podaje się trzy najczęściej stosowane testy weryfikujące. Pierwszym $\mathrm{z}$ nich jest test Walda, który stosuje się do testowania istotności efektów ustalonych (Geise, 2013). Na podstawie testu Hausmana dokonuje się wyboru między estymatorem efektów stałych a estymatorem losowych efektów indywidualnych (Hausman, 1978). Testowanie efektów losowych odbywa się natomiast przy wykorzystaniu testu Breuscha-Pagana (Breusch, Pagan, 1980).

W modelach panelowych skonstruowanych w ramach prezentowanych badań za zmienną objaśnianą przyjęto podstawową miarę wzrostu gospodarczego, jaką jest tempo 
wzrostu PKB mierzone procentowymi zmianami PKB względem roku poprzedniego. Zmiennymi objaśniającymi były zmienne opisujące poziom starości demograficznej w poszczególnych państwach UE. Stopień zaawansowania starości demograficznej może być oceniony przy wykorzystaniu wielu różnych miar. Najpopularniejsze $\mathrm{z}$ nich przedstawiają relacje między liczbą osób w określonych grupach wieku (Podogrodzka, 2016). W niniejszym opracowaniu jako zmienne objaśniające przyjęto stopę starości (udział ludności w wieku 65 lat i powyżej, tj. 65+, w ogólnej liczbie ludności) oraz miarę będącą jej uzupełnieniem, tj. współczynnik sędziwej starości (odsetek osób w wieku 80 lat i powyżej, tj. 80+, w populacji ogółem). Autorzy mają świadomość, że przyjęte do badań mierniki nie wyczerpują katalogu miar charakteryzujących proces starzenia się ludności. Ograniczono się jednak do dwóch wskazanych miar, jako jednych $\mathrm{z}$ podstawowych opisujących zmiany demograficzne w społeczeństwie.

Wyodrębniono trzy grupy modeli: dla 27 krajów UE łącznie (UE 27), dla krajów „starej” Unii (UE 15) oraz dla krajów „nowej” Unii (EŚW), tj. nowych państw członkowskich, które wstapiły do UE w 2004 r. bądź później.

\section{Wyniki badań}

Poziom starości demograficznej w najprostszy sposób można określić wyznaczając udział osób starszych w ogólnej liczbie ludności. Przyjmując za próg starości wiek 65 lat (Król, 2014) wyznacza się stopę starości (współczynnik starości), czyli udział osób w wieku 65 lat i więcej $\mathrm{w}$ populacji ogółem. Uzupełnieniem stopy starości jest współczynnik sędziwej starości obrazujący udział osób najstarszych (w wieku 80 lat i więcej) w liczbie ludności ogółem. Zmiany tych udziałów, obserwowane w latach 19962016 wskazują na wyraźnie postępujący proces starzenia się społeczeństw w krajach Unii Europejskiej (rys. 1).

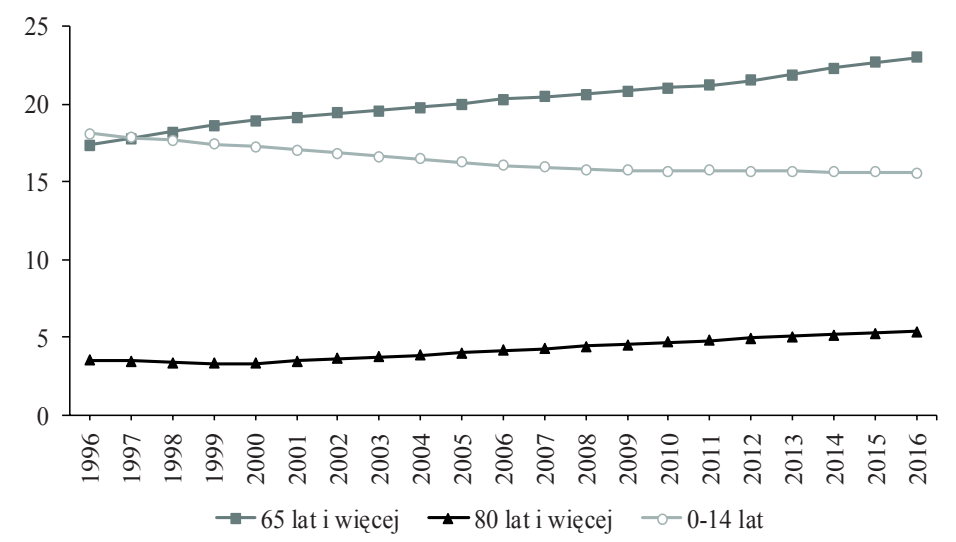

Rys. 1. Udział osób starszych i dzieci w ogólnej liczbie ludności (\%) w krajach UE w latach 1996-2016

Fig. 1. Percentage share of older people and children in the total population in EU countries in 1996-2016

Źródło: opracowanie własne na podstawie danych Eurostat. 
W badanym okresie 1996-2016, udział osób starszych (65+) wzrósł o 5,6 p.p., osiagając w 2016 r. poziom 23\%. Oznacza to, że już w 2016 r. blisko co czwarty mieszkaniec Unii Europejskiej osiągnął wiek co najmniej 65 lat, a prognozy demograficzne wskazują, że w ciągu kolejnych dziesięcioleci sytuacja będzie się pogarszać. Jednocześnie obserwuje się wzrostu udział osób sędziwych $(80+)$. Udział ten zwiększył się w badanym okresie o 1,9 p.p. Zaobserwowanym zmianom udziałów osób starszych i najstarszych towarzyszył spadek udziału dzieci (w wieku 0-14 lat) w populacji ogółem o 2,5 p.p. Postępujące przemiany demograficzne są tym bardziej niepokojące, że prowadzą do systematycznego kurczenia się zasobów siły roboczej oraz wzrostu liczby osób pobierających świadczenia emerytalne, przy zmniejszającej się liczbie osób finansujących te świadczenia.

Wzrost udziału osób starszych $(65+)$ oraz sędziwych $(80+)$ w populacji ogółem zaobserwowano w badanym okresie nie tylko globalnie - w całej Unii - ale również w każdym kraju członkowskim (rys. 2 i 3). Przy tym można zauważyć różnicę w poziomie starości w podziale na kraje „starej” Unii i „nowej” Unii. Mieszkańcy UE 15 są średnio starsi niż mieszkańcy nowych krajów członkowskich, jednak ta różnica maleje w czasie.

a) kraje „starej” Unii

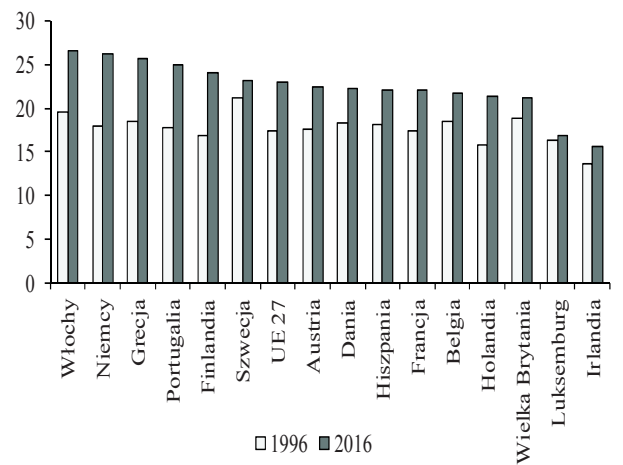

b) kraje „nowej” Unii

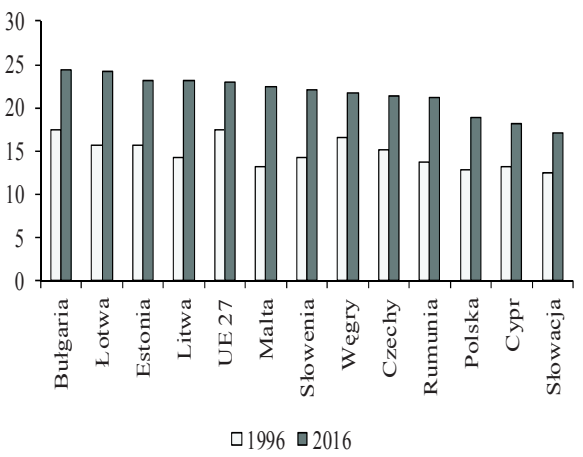

Rys. 2. Udział osób w wieku 65 lat i więcej w ogólnej liczbie ludności (\%) w krajach UE w 1996 r. i 2016 r.

Fig. 2. Percentage share of people aged 65 and more in the total population in the EU countries in 1996 and 2016

Źródło: opracowanie własne na podstawie danych Eurostat.

O ile w 1996 r. współczynnik starości demograficznej w krajach „starej” Unii wahał się w przedziale od $13,7 \%$ (w Irlandii) do 21,2\% (w Szwecji), to w krajach „nowej” Unii zamykał się w przedziale od 12,5\% (w Słowacji) do 17,4\% (w Bułgarii), przy czym w żadnym kraju „,nowej” Unii nie przekroczył średniej unijnej wynoszącej 17,4\%. Należy jednak zauważyć, że w 2016 r. różnice w poziomie starości obu grup krajów nie były już tak znaczne. Cztery kraje „nowej” Unii (Bułgaria, Łotwa, Estonia, Litwa) miały już, w 2016 r., stopę starości na poziomie wyższym niż średnia unijna równa 23,0\%.

Podobne tendencje zaobserwowano w odniesieniu do współczynnika sędziwej starości. Jednakże w tym przypadku udział osób w wieku 80 lat i więcej w krajach „,nowej” Unii utrzymał się na niższym poziomie niż w krajach „starej” Unii w całym badanym okresie. W żadnym kraju „nowej” Unii współczynnik ten nie przekroczył ani nie osiąnął średniej unijnej i w 2016 r. zamknął się w przedziale od 3,2\% (Słowacja) do 5,3\% (Litwa), 
podczas gdy wśród krajów UE 15 wahał się od 3,1\% (Irlandia) do 6,7\% (Włochy), przy średniej unijnej wynoszącej 5,4\%. Pogłębione badania w tym zakresie, potwierdzające zaobserwowane tendencje przeprowadziła E. Wasilewska (2017) konstruując rankingi krajów Unii Europejskiej z punktu widzenia zaawansowania starości demograficznej.

a) kraje „starej” Unii

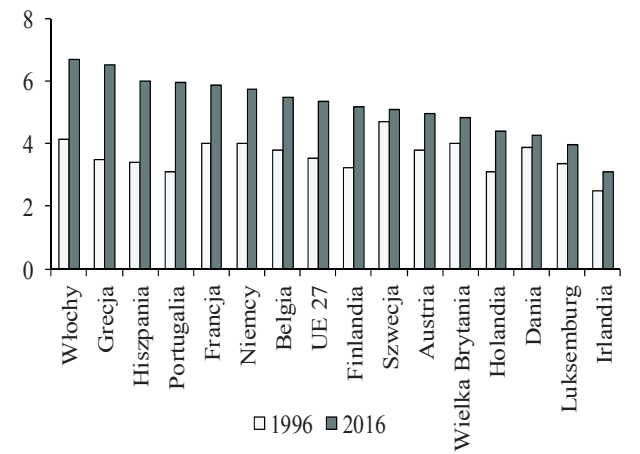

b) kraje „nowej” Unii

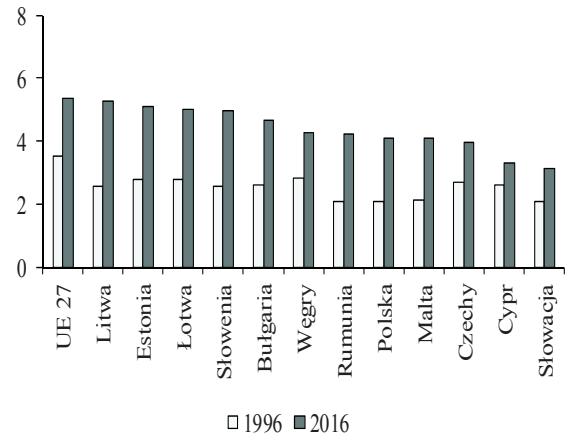

Rys. 3. Udział osób w wieku 80 lat i więcej w ogólnej liczbie ludności (\%) w krajach UE w 1996 r. i 2016 r.

Fig. 3. Percentage share of people aged 80 and more in the total population in the EU countries in 1996 and 2016

Źródło: opracowanie własne na podstawie danych Eurostat.

Aby zrealizować cel sformułowany we wstępie, przeprowadzono analizę empiryczną z wykorzystaniem danych panelowych. Ze względu na charakter danych rozważono trzy typy estymatorów: panelowy $M N K$, fixed effects $(F E)$ oraz random effects $(R E)$. Wyboru najwłaściwszego $\mathrm{z}$ nich dokonano drogą analizy heteroskedastyczności składnika losowego, z wykorzystaniem testów opisanych w części metodycznej. W pierwszym kroku za pomocą testu Walda badano, czy wprowadzenie zróżnicowanych wyrazów wolnych dla $i$-tych obiektów daje dokładniejsze oszacowania parametrów modelu danych panelowych. Następnie, badano założenia o stałości wariancji składnika losowego dla obiektów (test Breuscha-Pagana) oraz własności estymatorów $F E$ oraz $R E$, po czym dokonywano wyboru nieobciążonego estymatora (test Hausmana). Wyniki testów, wskazujące najodpowiedniejszą postać modelu panelowego zaprezentowano w tabeli 1.

W przypadku wszystkich krajów UE zarówno w modelu, w którym zmienną objaśniającą była stopa starości, jaki i odsetek osób 80+, w testach Walda oraz BreuschaPagana odrzucono hipotezę zerową o braku zróżnicowania efektów indywidualnych na korzyść hipotezy alternatywnej, uznając tym samym estymator $F E$, jako najbardziej odpowiedni w przypadku testu Walda oraz estymator $R E$, w przypadku testu BreuschaPagana. Rozstrzygnięcie problemu polegającego na wyborze najlepszego estymatora stanowił w tym przypadku test Hausmana, którego wynik wskazał na brak podstaw do odrzucenia hipotezy zerowej o występowaniu zgodności obu estymatorów - dla efektów ustalonych i efektów losowych, przy czym estymator efektów losowych był bardziej efektywny. Tak więc w świetle testu Hausmana, modelem efektywniejszym i tym samym najlepiej opisującym zmienność tempa wzrostu PKB w grupie wszystkich krajów UE był model z efektami losowymi $R E$.

Uwzględnienie w badaniu krajów jedynie „starej” UE spowodowało zmianę w wyborze estymatora do oszacowania parametrów modelu, w którym zmienną 
objaśniającą była stopa starości. W wyniku przeprowadzenia testu Walda stwierdzono brak podstaw do odrzucenia hipotezy zerowej o barku zróżnicowania efektów indywidualnych. Dodanie więc tych efektów jest zbyteczne, a estymator $M N K$, w przypadku modelu, w którym zmienną objaśniającą była stopa starości, jest najbardziej odpowiedni.

W przypadku modeli dla krajów „,nowej” UE, zarówno gdy zmienną objaśniającą była stopa starości jak i odsetek osób w wieku 80+, wykonane testy wskazały wybór estymatora MNK. Oznacza to, że w świetle testu Walda, modelami efektywniejszymi i tym samym najlepiej opisującymi zmienność tempa wzrostu PKB były w tym przypadku modele zakładające brak efektów indywidualnych (zbiorowość krajów „nowej” Unii była homogeniczna).

Tabela 1. Testy heteroskedastyczności dla modeli panelowych

Table 1 . Heteroscadasticity tests for panel models

\begin{tabular}{|c|c|c|c|}
\hline \multirow{2}{*}{ Testy } & \multicolumn{3}{|c|}{ Zmienna objaśniajaca - stopa starości } \\
\hline & wszystkie kraje UE & kraje „starej” UE & kraje „nowej” UE \\
\hline Test Walda & $\begin{array}{l}F(26 ; 539)=1,713 \\
\text { wartość } p=0,016\end{array}$ & $\begin{array}{c}F(14 ; 299)=1,048 \\
\text { wartość } p=0,405\end{array}$ & $\begin{array}{l}F(11 ; 239)=1,383 \\
\text { wartość } p=0,182\end{array}$ \\
\hline Test Breuscha-Pagana & $\begin{array}{c}L M=5,063 \\
\text { wartość } \mathrm{p}=0,024\end{array}$ & $\begin{array}{c}L M=0,004 \\
\text { wartość } \mathrm{p}=0,952\end{array}$ & $\begin{array}{c}L M=0,018 \\
\text { wartość } \mathrm{p}=0,892\end{array}$ \\
\hline Test Hausmana & $\begin{array}{c}H=0,173 \\
\text { wartość } p=0,678\end{array}$ & $\begin{array}{c}H=0,075 \\
\text { wartość } p=0,784\end{array}$ & $\begin{array}{c}H=4,785 \\
\text { wartość } p=0,029\end{array}$ \\
\hline Estymator: & $R E$ & $M N K$ & $M N K$ \\
\hline \multirow{2}{*}{ Testy } & \multicolumn{3}{|c|}{ Zmienna objaśniajaca - współczynnik sędziwej starości } \\
\hline & wszystkie kraje UE & kraje „starej”UE & kraje „nowej”UE \\
\hline Test Walda & $\begin{array}{l}F(26 ; 539)=1,581 \\
\text { wartość } p=0,035\end{array}$ & $\begin{array}{c}F(14 ; 299)=1,931 \\
\text { wartość } p=0,023\end{array}$ & $\begin{array}{c}F(11 ; 239)=1,279 \\
\text { wartość } p=0,237\end{array}$ \\
\hline Test Breuscha-Pagana & $\begin{array}{c}L M=3,189 \\
\text { wartość } p=0,074\end{array}$ & $\begin{array}{c}L M=4,322 \\
\text { wartość } p=0,038\end{array}$ & $\begin{array}{c}L M=0,089 \\
\text { wartość } p=0,765\end{array}$ \\
\hline Test Hausmana & $\begin{array}{c}H=0,543 \\
\text { wartość } p=0,461\end{array}$ & $\begin{array}{c}H=0,007 \\
\text { wartość } p=0,933\end{array}$ & $\begin{array}{c}H=3,265 \\
\text { wartość } p=0,071\end{array}$ \\
\hline Estymator: & $R E$ & $R E$ & $M N K$ \\
\hline
\end{tabular}

Źródło: obliczenia własne na podstawie danych Banku Światowego.

Wyniki oszacowań parametrów modeli panelowych uzyskanych przy zastosowaniu odpowiednich estymatorów przedstawiono w tabeli 2. Rozważając modele dla wszystkich krajów UE, krajów „starej” UE jak i „nowej” UE, we wszystkich przypadkach stwierdza się istotną zależność między zmiennymi objaśniającymi a tempem wzrostu PKB. Zarówno stopa starości (odsetek osób w wieku 65+ w populacji ogółem), jak i współczynnik sędziwej starości (odsetek osób w wieku 80+ w populacji ogółem) są ujemnie skorelowane z dynamiką PKB.

Najsilniejszą ujemną zależność między tempem wzrostu PKB a zmiennymi demograficznymi zaobserwowano w przypadku krajów „starej” Unii. Otrzymano tu dla stopy starości i współczynnika sędziwej starości oceny parametrów równe odpowiednio: $-0,446$ oraz $-1,521$. Oznacza to, że wraz ze wzrostem stopy starości o 1 p.p. tempo wzrostu PKB spada przeciętnie o 0,446 p.p., natomiast w przypadku zwiększenia o 1 p.p odsetka 
osób w wieku 80+, można oczekiwać spadku tempa wzrostu PKB o 1,521 p.p. Wynik taki jest merytorycznie uzasadniony, gdyż osoby młodsze w grupie $65+$ często jeszcze pracują, nie stanowia, więc tak dużego obciążenia dla wydatków publicznych jak osoby w wieku $80+$.

Tabela 2. Wyniki estymacji parametrów modeli panelowych

Table 2. Results for the estimation of parameters in panel models

\begin{tabular}{l|ccc}
\hline \multirow{2}{*}{ Wyszczególnienie } & \multicolumn{3}{c}{ Zmienna objaśniajaca - stopa starości } \\
& wszystkie kraje UE & kraje ,starej” UE & kraje „,nowej” UE \\
\hline Wartość parametru & $-0,351$ & $-0,446$ & $-0,153$ \\
Istotność & 0,000 & 0,000 & 0,073 \\
Wielkość panelu & 567 obserwacji & 315 obserwacji & 252 obserwacji \\
\hline \multirow{2}{*}{ Wyszczególnienie } & Zmienna objaśniająca- współczynnik sędziwej starości \\
& wszystkie kraje UE & kraje ,starej” UE & kraje „nowej” UE \\
\hline Wartość parametru & $-1,265$ & $-1,521$ & $-0,980$ \\
Istotność & 0,000 & 0,000 & 0,001 \\
Wielkość panelu & 567 obserwacji & 315 obserwacji & 252 obserwacji \\
\hline
\end{tabular}

Źródło: obliczenia własne na podstawie danych Banku Światowego.

Dla krajów „nowej” Unii odnotowano słabsze zależności między badanymi zmiennymi niż w przypadku krajów „starej” Unii. Ocena parametru dla zmiennej stopa starości wyniosła $-0,153$, co oznacza, że przy wzroście o 1 p.p odsetka osób w wieku 65+ oczekiwany spadek tempa wzrostu PKB wynosi 0,153 p.p. Natomiast w odniesieniu do odsetka osób najstarszych $(80+)$, ocena parametru równa jest $-0,980$, tak więc wzrost tego odsetka o 1 p.p. przekłada się na spadek tempa wzrostu PKB przeciętnie o 0,980 p.p.

Niekorzystna relacja między wzrostem gospodarczym a starzeniem się społeczeństwa może być rezultatem zarówno zmniejszenia zasobów siły roboczej, jak i ograniczenia możliwości inwestycyjnych wskutek malejących oszczędności - cechy charakterystycznej dla starzejącego się społeczeństwa (Urbaniak i in., 2015). Jednak przede wszystkim wzrastający udział osób starszych w społeczeństwie staje się coraz większym obciążeniem dla finansów publicznych z uwagi na wzrastające wydatki emerytalno-rentowe, koszty opieki zdrowotnej, koszty usług opiekuńczych dla osób starszych przy zmniejszającej się liczbie osób finansujących te wydatki.

Starzenie się społeczeństwa może przekładać się na spadek oszczędności obywateli. Ten z kolei przyczynia się do spadku inwestycji i wpływa hamująco na gospodarkę (Gradzewicz, 2016). Teoretyczną relację pomiędzy starzeniem się a skłonnością do oszczędzania opisuje hipoteza cyklu życia (ang. the life-cycle hypothesis). Zgodnie z ta hipotezą ludzie w podeszłym wieku oraz osoby młodsze, które kształcą się lub osiagają dochody na niskim poziomie, oszczędzając mniej, niż osoby w średnim wieku. Analiza literatury przedmiotu wskazuje jednakże, że kwestia empirycznej słuszności tej hipotezy jest nadal otwartym problemem badawczym. Szczególnie brak jest empirycznych dowodów na to, że ludzie mniej oszczędzają pod koniec swojego życia. Słabszy związek pomiędzy badanymi zmiennymi w krajach „,nowej” Unii można zatem tłumaczyć tym, iż w krajach tych współczynnik oszczędzania dla osób starszych może być wyższy, niż przewidywany 
zgodnie hipotezą cyklu życia, ze względu na motywację przezornościową oraz większą gotowość wspomagania dzieci w przyszłości (Chawla i in., 2007).

Warto wskazać, iż badania zależności między stopą starości a tempem wzrostu PKB w krajach Unii Europejskiej prowadzili też Urbaniak i inni $(2015$, s. 63). Według tych autorów „nie obserwuje się istotnego zróżnicowania między krajami „starej” i „nowej” UE pod względem oddziaływania udziału osób w wieku 65+ na tempo wzrostu PKB”. Należy wskazać, że badania prowadzone w ramach niniejszej pracy pozwoliły zauważyć istotne różnice między krajami „starej” i „nowej” Unii w tym zakresie. Stwierdzono, że negatywny wpływ starzenia się populacji jest silniejszy w krajach „starej” Unii niż w nowych krajach członkowskich. Warto podkreślić, że autorzy cytowanego opracowania (Urbaniak i in., 2015) stosowali bardzo uproszczone narzędzia badawcze, posługując się modelami regresji prostej konstruowanymi na podstawie danych uśrednionych, przy czym korzystali z danych pochodzących z krótkiego szeregu czasowego (2010-2013), co w zasadzie nie upoważnia do niebudzącego wątpliwości wnioskowania o występowaniu zależności przyczynowoskutkowej pomiędzy badanymi zmiennymi. Badania zaprezentowane w niniejszej pracy prowadzone były przy wykorzystaniu zaawansowanej analizy ekonometrycznej, stosowano modele panelowe, których użycie było uzasadnione z uwagi na występowanie efektów indywidualnych.

Rozważając relacje między procesami demograficznymi a wzrostem gospodarczym należy mieć na uwadze, że proces starzenia się społeczeństw może mieć również skutki pozytywne dla kreowania PKB. Należy podkreślić, że chociaż prognozy zmian demograficznych są pesymistyczne - zapowiadają możliwą destabilizację finansów publicznych, to $\mathrm{z}$ drugiej strony zaistniała sytuacja ekonomiczna może spowodować zagospodarowanie pewnej niszy rynkowej. W opinii niektórych ekonomistów proces starzenia się społeczeństw może mieć pozytywny wpływ na gospodarkę, poprzez pobudzanie zapotrzebowania na nowe produkty i usługi dostosowane do potrzeb osób starszych. W literaturze przedmiotu zostało nawet wypracowane pojęcie tzw. srebrnej gospodarki (ang. silver economy), czyli gospodarki, generującej usługi skierowane głównie do tej grupy wiekowej (Nietupska, 2015).

\section{Podsumowanie}

Analizy powiązań między demografią a ekonomią zyskują na znaczeniu z uwagi na coraz szybciej postępujący proces starzenia się społeczeństwa (wzrastający udział osób w wieku starszym w populacji). Szczególnie istotne są badania skutków, jakie niesie ten proces dla gospodarki. Pomimo tego, iż problem ten jest w literaturze oraz praktyce szeroko dyskutowany, to następstwa procesu demograficznego starzenia się ludności wciąż pozostają niedostatecznie rozpoznane. Wydaje się zatem celowe zbadanie procesu starzenia się społeczeństw oraz wpływu tego procesu na rozwój gospodarczy wieloma niezależnymi od siebie metodami.

W opracowaniu poddano analizie relację pomiędzy starzeniem się społeczeństwa krajów Unii Europejskiej a wzrostem gospodarczym przy wykorzystaniu modeli panelowych. Zaprezentowane modele pozwoliły wskazać, iż wzrost gospodarczy jest ujemnie skorelowany ze starzeniem się społeczeństwa. Stwierdzono, że ujemny wpływ zmiennych demograficznych, tj. stopy starości (odsetka osób w wieku $65+\mathrm{w}$ populacji) i współczynnika sędziwej starości (odsetka osób w wieku 80+ w populacji) jest silniejszy 
w krajach „starej” Unii w porównaniu z krajami „nowej” Unii. Otrzymane współczynniki regresji odpowiadające stopie starości i współczynnikowi sędziwej starości w modelach dla krajów „starej” Unii wynosiły odpowiednio: $-0,446$ oraz $-1,521$, podczas gdy dla krajów „nowej” Unii były równe: $-0,153$ (dla stopy starości) oraz $-0,980$ (dla współczynnika sędziwej starości).

Warto nadmienić, że zaprezentowane modele nie wyczerpują katalogu zmiennych objaśniających dynamikę wzrostu gospodarczego. W celu opracowania modeli, które w pełniejszym stopniu opisywałyby analizowany problem, należałoby włączyć inne zmienne makroekonomiczne, w tym zmienne opisujące $\mathrm{w}$ pełniejszy sposób sytuację demograficzną $w$ poszczególnych krajach. Tak więc problem zasygnalizowany w niniejszym opracowaniu wymaga dalszych, pogłębionych badań. Badania w tym zakresie mogą być pomocne wokreślaniu i usuwaniu negatywnych następstw starzenia się społeczeństwa oraz dostosowaniu instrumentów wspierania rozwoju społecznogospodarczego na szczeblu europejskim jak i krajowym.

Rozważając relacje między starzeniem się społeczeństwa a wzrostem gospodarczym, należy mieć na uwadze - oprócz zagrożeń dla gospodarki, jakie niesie ze sobą zwiększająca się liczba osób starszych - również aspekty pozytywne. W krajach rozwiniętych ujawnia się tzw. srebrna gospodarka, która $\mathrm{w}$ istotnym stopniu korzysta $\mathrm{z}$ doświadczeń osób starszych na rynku pracy. Przede wszystkim jednak postrzega te osoby jako ważną grupe konsumentów, o zwiększającym się znaczeniu rynkowym i o specyficznych potrzebach. Zaspokajanie tych potrzeb pozytywnie wpływa na kreowanie PKB, stając się szansa na rozwój gospodarczy.

\section{Literatura}

Andreß, H-J., Golsch, K., Schmidt-Catran, A. (2013). Applied Panel Data Analysis for Economic and Social Surveys. Springer.

Baltagi, B.H. (2005). Econometric Analysis of Panel Data (3rd ed.). John Wiley \& Sons Ltd, Londyn.

Bloom, D.E., Canning, D., Sevilla, J. (2003). The Demographic Dividend. A New Perspective on the Economic Consequences of Population Change, A RAHD Program of Policy-Relevant Research Communication.

Breusch, T.S., Pagan, A.R. (1980). The Lagrange multiplier test and its applications to model specification in econometrics. The Review of Economic Studies, 47(1), 239-253.

Chawla, M., Betcherman, G., Banerji, A. (2007). From Red to Grey: The „Third Transition” og Aging Populations in Eastern Europe and former Soviet Union, The World Bank, Washington.

Dańska-Borsiak, B. (2009). Zastosowania panelowych modeli dynamicznych w badaniach mikroekonomicznych i makroekonomicznych (Dynamic panel data models in microeconomic and macroeconomic research). Przeglad Statystyczny, 56(2), 25-41.

Dańska-Borsiak, B. (2011). Dynamiczne modele panelowe w badaniach ekonomicznych (Dynamic panel models in economic research). Wydawnictwo Uniwersytetu Łódzkiego, Łódź.

Dougherty, C. (2011). Introduction to Econometrics, Oxford University Press, New York.

Florczak, W., Przybyliński, M. (2016). Zmiany w liczebności i strukturze populacji a rozwój społecznoekonomiczny (Changes in the population size and structure and socio-economic growth development). Studia Ekonomiczne - Economic Studies, 3(90), 396-422.

Geise, A. (2013). Przestrzenno-czasowe modelowanie zmienności produkcji w sektorach mikro-, małych, średnich i dużych przedsiębiorstw w Polsce (Time-spatial modelling of the variability of production in sectors of micro, small, medium and large enterprises in Poland). Przeglad Statystyczny, 60(2), 269-282.

Gradzewicz, M. (2016). Zawiłe relacje między demografią a polityką pieniężną (Complex relations between demography and monetary policy). Pobrane 20 kwietnia 2018 z: https://www.nbp.pl/badania/seminaria/ 7x2016.pdf.

Hausman, J. (1978). Specification tests in econometrics. Econometrica, 46, 1251-1271. 
Jurek, Ł. (2012). Ekonomia starzejącego się społeczeństwa (Economics of an aging society). Wydawnictwo Difin SA, Warszawa, 23.

Król, M. (2014). Starzenie się populacji Polski (Population ageing in Poland). (W:) Współczesna polityka gospodarcza i społeczna (Contemporary economic and social policy). Przegląd Nauk Stosowanych, nr 4, M. Król (red.). Gliwicka Wyższa Szkoła Przedsiębiorczości, Gliwice, 9-21.

Maddala, D.S. (2008). Ekonometria (Econometrics). Wydawnictwo Naukowe PWN, Warszawa.

Mátyás, L., Sevestre, P. (red.). (2008). The Econometrics of Panel Data. Fundamentals and Recent Developments in Theory and Practice. Springer, Third Edition.

Mączyńska, E. (2010). Przełom cywilizacyjny a wzrost gospodarczy. Niedoceniane aspekty demograficzne (Civilization breakthrough and economic growth. Undervalued demographic aspects). Rządowa Rada Ludnościowa, Biuletyn 55, 18-28. Pobrane 10 kwietnia 2018 z: https://stat.gov.pl/cps/rde/xbcr/bip/ BIP_biuletyn55.pdf.

Nietupska, A. (2015). Wpływ zmian demograficznych na ekonomiczne zabezpieczenie starości społeczeństwa w Polsce (The influence of demographic changes on the economic safety of the old age of society in Poland). Społeczeństwo i Ekonomia, 1(3), 33-46.

Podogrodzka, M. (2016). Wybrane miary starości demograficznej i ich implikacja dla oceny przestrzennego zróżnicowania tego zjawiska w Polsce (Chosen measures of the demographic old age and their implication for the spatial diversifying this phenomen in Poland). Studia Ekonomiczne. Zeszyty Naukowe Uniwersytetu Ekonomicznego w Katowicach, 289, 98-108.

Podstawowe pojęcia i rozwój teorii demografii na przestrzeni dziejów (Basic concepts and development of the theory of demography throughout history). (2013). Sigma kwadrat. Czwarty Lubelski Konkurs Statystyczno-Demograficzny, Lublin. Pobrane 8 kwietnia 2018 z http://sigma.wszia.edu.pl/wpcontent/uploads/w6-podstawowe-pojecia-demografii.pdf.

Strzelecki, Z. (2012). Główne zagrożenia globalne dla Polski (Main threats for Poland). Przyszłość. Świat-EuropaPolska, $\mathrm{nr} 2 / 26, \quad 43-50$. Pobrane 8 kwietnia 2018 z: http://yadda.icm.edu.pl/yadda/element/ bwmeta1...d2d9.../2-26 Zbigniew Strzelecki.pdf.

Śleszyński, T.P. (2010). Znaczenie przemian demograficznych w przestrzeni Polski dla rozwoju gospodarczego (The significance of demographic changes in Poland's space for economic development). Rządowa Rada Ludnościowa, Biuletyn 55, 49-71. Pobrane 10 kwietnia 2018 z: https://stat.gov.pl/cps/rde/ xbcr/bip/BIP_biuletyn55.pdf.

Urbaniak, B., Gładzicka-Janowska, A., Żyra, J., Kaliszczak, L., Piekutowska, A., Rollnik-Sadowska, E., Sobolewska-Poniedziałek, E., Niewiadomska A., Gagacka, M. (2015). Socjoekonomika starzenia się współczesnych społeczeństw (Socioeconomics of aging of modern societies). Wydawnictwo CeDeWu, Warszawa, 53-71.

Wasilewska, E. (2017). Demographical Ageing of the EU Member States' Societies. Scientific Journal Warsaw University of Life Sciences - SGGW, Problems of World Agriculture,17(4), 302-315.

Zając, K. (2007). Z historii badań związków rozwoju społeczno-ekonomicznego a demograficznego (From the history of research on relationships of socio-economic development and demographic). Wyższa Szkoła Ekonomii, Turystyki i Nauk Społecznych w Kielcach, 1-15. Pobrane 8 kwietnia 2018 z: https://stat. gov.pl/ $\mathrm{cps} / \mathrm{rde} / \mathrm{xbcr} / \mathrm{gus} / \mathrm{POZ} Z \mathrm{Z}$ historii_badan_zwiazkow_rozwoju_spol-ekonom_a_demogr.pdf.

\section{Do cytowania / For citation:}

Wasilewska E., Pietrych Ł. (2018). Starzenie się społeczeństwa a wzrost gospodarczy w krajach Unii Europejskiej. Problemy Rolnictwa Światowego, 18(4), 481-492; DOI: 10.22630/PRS.2018.18.4.136

Wasilewska E., Pietrych Ł. (2018). Demographical Ageing and Economic Growth in the UE Countries (in Polish). Problems of World Agriculture, 18(4), 481-492; DOI: 10.22630/PRS.2018.18.4.136 